\title{
Textile semantics: perception and memory
}

\author{
S. Andrew \\ University of Huddersfield, School of Art, Design and Architecture, UK
}

This paper focuses on a semiotic exploration of textiles, examining the relationship between the designer's authorial intention as the maker and the interpretation of their work by the viewer, particularly how visual images within textiles are read, and if the designer shares a common 'visual grammar' with their audience. The first stage of the paper discusses cultural perceptions of the tactile qualities of textiles and how the visual image in textiles has been used to communicate with the viewer. The role of context as an influencing factor in the meaning generated from image and cloth/fabric, and the dominant cultural codes by which textiles are read, are considered. The second stage examines viewer perceptions of a printed textile installation designed to communicate a family history narrative. Viewers' interpretations of the narrative and the installation sites are discussed, highlighting examples where personal memory and shared cultural memory influenced their responses.

\section{INTRODUCTION}

Individual memory is built from many facets, mediated through different communication channels it incorporates perceptions transmitted from those with whom we have formative and on-going relationships, and the shared experiences (real, virtual or hyper-real) that form our collective cultural memory. Erll (2008) notes that the material (artefacts, media), the social (people, social relations, institutions), and the cognitive (culturally defined ways of thinking) contribute to the formation of cultural memory. Viewer interpretations of textiles and the context in which they are used or viewed, are informed by both individual memory and shared cultural memory, which act as triggers for the generation of shared perceptions that in semiotic terms reveal dominant cultural codes of meaning.

\subsection{Tactility and perception}

Although we may think that we respond individually to how a textile looks and feels, a survey of viewer perceptions of textile samples suggests that our fundamental responses to many textiles are culturally learned (Andrew, 2008), creating a hierarchy of meanings associated with each fabric. When viewers were asked to match descriptions such as expensive, cheap, luxurious or hardwearing to unnamed fabric samples that they could touch, most respondents recorded similar attributes for Pahjah raw silk as for jute. When these fabrics were shown as named samples in a duplicate survey, most viewers gave different attributes to these two fabrics. The word 'silk', rather than the experience of the fabric itself, elicited a learned cultural response from viewers that silk was more refined, expensive and luxurious (Andrew, 2008).

The meanings we derive from textiles are learnt from an early age and their meanings become culturally embedded. Whilst some fabrics are associated with luxury, others are associated with work wear. Barnard (1996) acknowledges the communication potential of the perceived qualities of textiles and how this can be a highly effective tool in advertising. He notes that the connotations of textiles such as linen and flannel have been used in advertising fragrances, whilst silk is often associated with hair products and cosmetics.

A brand of chocolate is well known in Britain for employing the "why have cotton when you can have silk' strapline in their television advertising campaigns (www.campaignlive.co.uk), successfully associating chocolate with qualities attributed to a textile by asserting the luxurious connotation of silk over the functional, everyday connotation of cotton. Pairing this with an up-market, low-lit apartment and the musical introduction to Rhapsody in Blue in their television advertising in the late 1980's, a sense of anticipation and indulgence was communicated. Even the lamp in the apartment, a serpent design, functioned as a signifier of the Garden of Eden and 
temptation. By 1992 the company updated the television advert and added a 'why have cotton when you can have silk' voice-over to clearly articulate the associations between their product and the qualities of silk, using a chocolate coloured Dior dress to denote silk and provide the added connotations of taste and wealth. Recent adverts for the chocolate still include the textile comparison strapline.

\subsection{Context and perception}

Dominant cultural readings of textiles are pervasive. Responses to textiles are developed through our first childhood encounters with the tactile qualities of woven cloth and knitted fabric, but cultural influences later inform our responses to textiles. These are then subject to perceptions of the product they are made into, and the context in which they are viewed. Davis (1992) and Kaiser (2002) examine the context dependence of clothing messages, where garment and context impose their own layer of meaning on our understanding of the textile. Davis exemplifies this through the different meanings generated by black lace in a funeral veil as opposed to a nightgown. Black lace is a (redundant) signifier of lingerie, as lingerie is the dominant reading of the textile in many western cultures.

When we see an image, or form a mental picture of it, we rely on a mix of dominant cultural codes and memory to decode it. Dominant codes create shared understanding by conveying the preferred (or majority) values and cultural perceptions of a society. Dominant codes are those we expect. They are known as 'broadcast codes' (Fiske, 2010) as they operate on the basis of commonality and rely on cultural understanding that the majority of people share. We become aware of 'broadcast codes' informally through day-to-day experience from childhood through to adulthood. However, codes are informed by many different facets of cultural knowledge, ideology and personal experience, and the expected meaning we try to communicate through what we perceive as the shared dominant codes of a particular group might not be received in the way we intend. In some cultures black lace may signify 'funeral veil' but it is likely to be a subcultural reading of the textile, not the dominant reading. This reading of black lace could be categorised as aberrant decoding (Eco, 1977; Fiske, 2010). 'Funeral veil' may have been the dominant cultural code associated with black lace in western cultures in the past, but it is in marked contrast to the dominant cultural perception of the textile in western cultures now. Context can change this; if a person were standing in a church and asked to think of black lace, a dominant cultural reading of 'funeral veil' would not be surprising. Denim also elicits a strong learned cultural response concerning the meaning of the cloth and the contexts in which it is seen, making a denim wedding dress an unlikely choice due to the connotations of the cloth and the shared cultural memory associated with it.

\subsection{Dominant cultural codes in textile practice}

Artists and designers can mix and subvert the cultural codes that are commonly use to understand images and textiles, but only if they have a good understanding of what the dominant cultural codes and subcodes are that apply to the images and textiles in any given context. Dolce and Gabbana incorporate lace and successfully reference both lingerie and funeral attire in garments described as their 'Sicilian widow look', whilst Yinka Shonibare's works such 'Dressing Down Textiles in a Victorian Philanthropist's Parlour' (1996-7) and 'Scramble for Africa' (2003) incorporate 'African' printed textiles into Victorian costume. This change of context forces the viewer to consider the contrast in meanings communicated by the printed cloth and the garment shape, challenging their perceptions of cultural identity and colonialism and actively subverting dominant cultural codes. Jefferies (2008: 51) notes:

The history of fabric used, the ambiguous materials and motifs of west African textiles, seem to symbolize the rich complexity of post-colonial cultures in that, while the patterns and colours are thought to be authentically African, they actually originate from Indonesian Batik work, a technique which was industrialised by Dutch traders historically active in Africa.

Shonibare's re-contextualisation of the printed textiles in Victorian costume is effective because the dominant cultural reading of the patterns and printing style is that they are typically 'African'.

Paddy Hartley's work 'Project Façade' (20072008) exemplifies communication through the relationship between the visual content in the work, the object itself, and the context it is viewed in. His pieces communicate the stories of WW1 service men that had pioneering facial reconstruction surgery. The pattern cutting and stitching back together on the facial masks echo the process of the surgery, with image and text on the soldiers' experiences combined into modified army uniforms (Figure 1). Exhibited at the Imperial War Museum, the relationship between content, object and context is unified. Hartley works within the parameters of dominant cultural codes to enable the viewer to deal with difficult subject matter.

Nina Edge particularly utilises clothing as a form of political activism. Her exhibition 'Terra' (2005) included camouflage hijabs to emphasise differences in ideology between cultures. Floral textiles were embroidered with fighter jets and camouflage fabrics embroidered with flowers to communicate and contrast the impact of the military on the domestic and vice versa. In Shelley Goldsmith's work printed images of natural disasters were used to communicate human vulnerability, such as the piece 'Baptism' 
(2003). The use of this type of printed image within infant dresses adds an additional level of meaning to viewers' perceptions. The viewer reads meaning into the image and the garment simultaneously, making connections between the disaster and the child's dress.

\subsection{Dominant cultural codes and gender}

Some of the most pervasive dominant cultural codes apply to the use of colour and image in printed textiles for children's products that reinforce gender perceptions. A British high street retailer was highlighted by the campaign group 'Let Clothes Be Clothes' in January 2015 for manufacturing and marketing Natural History Museum clothing with dinosaur images only for boys (Hill, 2015). In an open letter to the company the campaign group provided examples of their t-shirts with printed images of kittens for girls and 'bug expert' for boys, noting that the textiles in coats for girls were described as 'cosy and dry' and 'pretty and practical', whilst the textiles in boys coats were described as 'made with a host of clever fabric technologies to ensure maximum durability and long wear' (https://letclothesbeclothes.uk). Highlighting the 2011 Bailey review (www.gov.uk), the campaign group raised issues such as age appropriate fit and coverage of clothing, and the lack of gender-neutral clothing, across a range of retailers.

As one of the highest crowd funded children's clothing projects in Kickstarter history to date, the Princess Awesome brand have rejected typical images for girls and pink colour palettes on their clothing, in a small step against the dominant cultural codes associated with gender. The aim of the brand is to produce clothing for girls that features prints such as dinosaurs, robots and transport, images that are more usually associated with boyswear. The response from consumers has been positive. Creators Eva Saint Claire and Rebecca Melsky state 'It shows that parents and children alike are rejecting the gendered straightjacket that mass consumer culture forces them into' (St Claire, 2015, quoted in Hill, 2015: $10)$. The images on the clothing communicate a different message to the viewer about the child wearing it and to the child themselves. St Claire states:

This matters for so many reasons. When people meet a little girl in a pink, sparkly dress, they talk to her about how sweet and pretty she looks. If she's wearing a dress with robots or trains on, they'll talk to her about them instead - that is, about technology and engineering. That opens up her mind, her world and her future. (St Claire, 2015, quoted in Hill, 2015: 10).

\subsection{Printed textiles as communication}

The idea of using printed textiles to communicate with both user and viewer is not a recent phenomenon. Historically 'conversational prints' were de- signed with figurative images (stylised or realistic) to convey a simple narrative or message. In World War One St John's Ambulance slings were printed with instructions for tying bandages and tourniquets (Figure 2) and several British fabrics produced in the 1940 's functioned as both conversational prints and propaganda. The dress fabric 'Coupons' (1941-42) by the Calico Printer's Association notes how many coupons are needed to purchase each garment shown in the print, whilst 'Victory V' (1941) aimed to boost morale and demonstrate the patriotism of the wearer (http://collections.vam.ac.uk).

Toile de Jouy is a particular example of textiles as communication where the visual narrative tradition can be traced through to contemporary practice. The printed cloth was originally produced in Jouy en Josas, France, from 1760 to 1843 (Bredif, 1989) for interior furnishings and fashion fabrics. The first prints incorporated idealised scenes of country life but designs were also created to commemorate specific events. The tradition continued, with 1930's art deco examples by Ruth Reeves such as 'Manhattan' showing idealised vignettes of industry and city life within the repeat composition. But 'Glasgow Toile' (2004) by Scottish print company Timorous Beasties demonstrated a more contemporary interpretation of the toile de Jouy tradition. This interior fabric moves away from idealised scenes to a more subversive and realistic version of life in a modern city. Kent Henricksen's treatment of toile de Jouy takes this a step further using print and embroidery to add ominous masked figures within ornate repeat designs such as 'Absence of Myth' (2007), exploring themes of violence, submission and slavery.

Subversive prints are more common within fashion, particularly where a designer external to the brand alters a company logo to convey a new message. Wayne Hemmingway modified the Shell oil company logo to read Hell, and changed the Hoover domestic products logo to the less controversial Groover for a range of Red or Dead t-shirts in the 1990's. More recently design company Liquid Sky adapted the adidas logo for their 'abducted' t-shirt and Judy Blame changed the 'Keep Britain Tidy' campaign image into 'Keep the World Tidy' with the campaign figure discarding a swastika symbol.

\subsection{Paradigmatic and syntagmatic choices}

In the construction of their work, all artists and designers make 'paradigmatic' and 'syntagmatic' choices. These terms originally derive from linguistics (Saussure, 1983) and apply to the choices we all make when we communicate, choices that are often subliminal and instantaneous. Fiske (2010: 62) notes that 'paradigms are composed of units with an overall similarity, but with distinctive features that distinguish them from one another'. In semiotic terms these units are called 'signs'. A sign is made up of 
the signifier (such as the object, word, image, sound, taste or smell) and it's signified meaning to the viewer (Barthes, 1967). A syntagm is the message into which chosen signs are combined. All messages involve selection (from a paradigm) and combination (into a syntagm), whether they are visual, spoken or written (Fiske, 2010). Consider religious icons; instead of selecting one signifier and its signified meaning from the paradigm of 'religious icons' to create a printed textile design, Wayne Hemmingway of Red or Dead chose many religious icons and combined these in a visual syntagm in the form of a print entitled 'Guru' (1997). This had to be withdrawn after protests from a range of religious communities who did not want their religious icons, and what each of them signified, associated with the meanings of others, or with the term 'Guru' (Kingswell, 1998). Artists and designers also undertake what Roland Barthes (1967) described as 'commutation tests'. This test is primarily one of substitution where alternative signifiers are considered and evaluated in terms of their effect on the meaning generated. Commutation tests function as conscious or subconscious, instinctive actions within the on-going practice of design. The designer carries out successive cycles of selection and elimination as they analyse, for example, the substitution of one image for another within a composition and its impact on the compositional relationship and meaning of the work.

\section{PERCEPTIONS OF A TEXTILE INSTALLATION}

Many textile practitioners are concerned with narrative in one form or another, as stories play a significant role in the continuity of cultural knowledge and traditions. Millar (2007) notes that visual narratives are particularly context dependent, that they can be renegotiated as social situations change and are open to subjective editing by the viewer. We set out to visually communicate, but is shared meaning between the maker and their audience generated in the way the practitioner intends?

Perception, memory and subjectivity in the representation and interpretation of visual narratives formed the basis of a research project to test how meanings encoded in printed textiles by the maker were decoded by viewers. A visual narrative was constructed based on the experiences of John Edgar Bell, a Quaker and conscientious objector in WW1, who was imprisoned for refusing to fight. Two installations, each consisting of three textile panels were produced. The panels were designed to communicate the family at the start of the war and the social exclusion they faced, the imprisonment of the conscientious objector, and the hostility towards the objector's family that continued into WW2 and beyond. The panels were located in galleries, muse- ums, churches and corporate spaces without any title or description to collect over 450 viewer interpretations of the textiles via 1:1 interviews and selfcompletion questionnaires. Colour images of the textile installations can be found at:

http://www.ahrc.ac.uk/research/readwatchlisten/imagegallery/2 014galleries/atextilenarrativeofjohnedgarbellconscientiousobje ctor/

Initially, relationships between photographic images and other visual signifiers such as colour and mark were explored to create micro visual syntagms and consider the meanings they might convey. This was supplemented by investigation into the experiences of pacifists and their families in WW1, contacting English Heritage to arrange access to Richmond Castle to photograph the cells where objectors were imprisoned.

The textile development progressed with paper, digital, and cloth experiments. Specific images were incorporated to develop the visual narrative, such as crossed out medals to connote lack of bravery, white feathers as symbols to signify cowardice, and stamps to denote the era (and suggest 'for king and country') (Figure 3). Due to John Edgar Bell's conscientious objection, the family experienced abuse from their community, with graffiti and crosses scrawled on the door of their home. This was translated into the textile work through printed and stitched crosses and brush marks over and around key signifiers in the panels. Images such as small white crosses, to serve a dual communication function as a Christian symbol and a grave marker, and crossed out medals, were included in the first installation panels. These images were expected to operate via broadcast codes and create shared interpretations from viewers. Other printed elements, such as crossed keys, operated via 'narrowcast codes' (Fiske, 2010), in that only a few individuals might know their correct meaning as a Christian symbol relating to Saint Peter. In the first installation shadows of prison bars were imposed over the image of the objector and a uniform pattern placed under his image (uniforms were thrown into imprisoned objector's cells on a daily basis, wearing the uniform was agreement to conscription).

\subsection{Installation one}

The predominant reading of the first installation was that the panels communicated a war narrative, with themes linking war, family and suffering emerging in viewer responses. Aberrant decoding was evident in some responses, such as the installation communicating 'nature versus the developed world' from one participant. Only a small number of viewers stated that the panels related to conscientious objection.

The crossed out medals were incorporated as an anti-war/anti-heroism signifier, to indicate the objector's beliefs, his refusal to fight and his perceived 
lack of bravery by society. It was expected that they would be very redundant signifiers and easily understood, but the majority of viewers did not perceive the crossed out medals an as anti-war statement, or connoting non-participation in the war effort. Fighting in the war, bravery, heroism, war dead and military were the predominant readings. The medals were removed in the development of the second installation panels but images to specifically denote WW1 replaced them, such as guns, bombs and warships.

Responses to the first installation revealed that most viewers' associated the small white crosses with graves rather than Christianity; so larger decorative examples were incorporated into the development work for the second installation. Most viewers interpreted the feather correctly but others suggested it represented 'pigeon carriers at the front line', 'elements of nature', 'a symbol of peace and love' and 'a writing implement'. Very few readings of the first installation related to imprisonment, and the prison bar shadows as a signifier were too subtle and were not noted in any responses. The second installation therefore incorporated images with greater semiotic redundancy (barbed wire, tally marks and lock) to generate the imprisonment reading. A key was later added to reinforce this, but also suggest potential for release.

\subsection{Installation two}

Interpretations of pacifist meanings increased in responses to the second installation and shared interpretations of the panels included war and wartime, imprisonment, suffering, and family relationships (some in relation to war). Aberrant decoding was still evident though, with one viewer interpreting the visual narrative as:

The struggle of non-British man travelling to Britain on work related journey. He is out to earn to maintain his family, however, encounters problems and is left with choice to go without much or stay and prosper with new family. He ends up doing the latter, which involved breaking his marital oath and religious law, and separating him from previous family. Ultimately his new offspring inherit British status.

The image of the ship (Figure 4) predominantly signified war and defence to viewers, but was also interpreted as migration. One viewer described the warship as a steamer signifying emigration to America or Australia. Their overall reading of the installation was 'Family history, imprisonment, emigration, disposal, memory'. The praying, tied and bandaged hands across the second installation panels created meanings of 'Hope for the future but trapped in a fast changing world', and 'Ties to enforced ideas'. One viewer read the hands in each panel as a micro narrative of 'Praying? Then shackled, then bandaged, track history of the man, was his objection from religious causes - sacrifice of human life?' Aberrant decoding of the hands included 'swearing in the oath of allegiance to the king' and marital breakup. Readings of imprisonment increased in responses to the second installation, with prisoner of war, POW camp and internment noted. One viewer described the 'face of man behind barbed wire' as 'a prisoner of war or deserter condemned to firing squad', another described the figure as 'priest, persecution for religion'. The larger decorative crosses incorporated in the second installation generated the intended interpretations of religion. One viewer noted 'As seen on the pulpit/altar, must be something to do with pacifism and church, being against war'. The decorative nature of the crosses, combined with the increase in scale, generated a shift in the signification of the imagery towards religious meanings in the second installation. The image of the family and white feather was intended to communicate the ongoing ostracism they faced in the years after WW1. One viewer particularly interpreted this image as 'carrying disgrace of white feather, suffering through loss and convictions of others, betrayal of country and church to support them'; others suggested 'defence of family (pressures to go to war)'. Photographic portraits across the panels generated readings related to family and the impact of war, particularly loss, suffering, love, absence and separation, such as 'the fragility of an individual family in a wartime situation' and 'innocent people caught up in wartime events not of their own making'. The photographs led some viewers to reflect on memories of friends and family histories, one viewer responding that the woman and barbed wire (Figure 5) reminded them of 'someone I knew who was in an internment camp as a child in World War Two', another stated 'memories evoked of my own family photos', whilst one viewer described the 'fear in woman's eyes' as meaning 'ambiguity of serving England'.

\subsection{Impact of location}

The influence of context on interpretations of the installation clearly emerged at some sites, with viewers associating the images with the history of the area, and some to their own family histories, rather than the intended conscientious objection narrative.

Saltaire United Reformed Church was chosen as a site because the religious context had a direct relationship to the content of the work. But the geographical area also had a history of textile manufacturing, with Salts textile mill located opposite the church, and both buildings being part of Saltaire village, a world heritage site. John Edgar Bell and his family had lived in Saltaire. This formed a link between the content of the work and the context of the church and surrounding area. Interpretations of the installation at the church included: 
The social and economic history of Saltaire presented by work, duty, family, church and environment. The link with textile industry and Saltaire.

Context in Saltaire made me think of industrial heritage, also family photos. Northern industrial towns, factory life and culture - the material itself reflects these qualities.

Firstly the church, the way it sits in the church. It makes you think more about it; also your senses are being stimulated, because of where it is.

Others viewers stated the meaning of the narrative as:

Family life connected to the church. The involvement of mills and woollen products during the war.

It reminds me of my family (grandmother, aunt, uncle, cousins) who worked in Salts Mill.

Maybe some sort of link with textiles but that might just be because of where we are.

Walford Mill Gallery and Lloyds TSB banking headquarters provided 'neutral' contexts, as the work had no relationship to the function of the buildings, or the history of the surrounding area. Lloyds also offered a corporate context for the installation that was not a feature of other sites in the study. But viewers at this site were still influenced by context in their reading of the narrative:

The key, is that perhaps some reference to the, you know, the lock works? I just thought we were looking at Birmingham and the bigger picture, Birmingham and the immediate surrounds.

Is it all to do with local history? Well, I mean, most of it comes from Willinghall, which is like a big lock making, or used to be a big lock making area, so that was the one thing I thought of, but I think you'd only pick up on that if you lived in that sort of area.

Sort of got history to it I guess, it's probably locally relevant some how. It certainly looks like it's probably something round here but I'm not from Birmingham so I'm not sure.

Manchester Museum of Science and Industry was included in the study as it provided a historical context related to textiles and the geographical area also had a history of textile manufacturing. The work was shown in the textile gallery of the museum that had displays of working textile machinery and exhibits relating to Manchester's historic role in the cotton trade. Several responses about the meaning of the installation at this site reflected this heritage:

The panels are representative of the development of the textiles industry interspersed with historical artefacts mostly relating to imperialism.

Conveyed the convergence of people to Manchester to work in the textile mills.

The true cost of our textiles. The struggles of early manufacturing and price paid by workers with their heath and lives.
Are the plants depicted cotton? If so it could show the link with Manchester.

I assume by the fact that it's here it is to do with possibly the production of cotton or some sort of other industry.

They're obviously very old images aren't they; I would guess that they are representing something of the heritage of the industry of this area.

From what I can see it looks like something that relates to this museum.

Viewers across the sites also responded to the way the work was made, with comments such as:

Feeling of past wars through aged textiles and photographs. Lack of support from country and church. We would not have spent as much time interpreting the works in other mediums.

Textiles have an added meaning to me - the history of cloth everyday use and the fading/rotting qualities that evoke memories of their own.

Materiality of textiles always speaks of history to me.

The textile panelling gives a feeling of both antiquity and reality which I feel wouldn't exist in another medium.

Textiles 'carry' history more intrinsically than other media they are quite literally amplified with memory of life lived. The texture and worn nature of these pieces vividly convey the aspect of a personal memorial.

\section{SUMMARY}

Olick (2010:156) notes that groups share 'publicly articulated images of collective pasts' but questions whether individual memory and collective memory are really separate things as collective memory refers to 'a wide variety of mnemonic products and practices, often quite different from one another' (Olick, 2010: 158) and mnemonic practices are simultaneously both individual and social.

The development of the textiles as a memorial to a family history was a form of mnemonic practice. Although communication intentions for the textile panels were specific, each image and composition was open to multiple interpretations. No single signifier in the work elicited a consistent interpretation from all viewers. The readings of visual syntagms within the textiles were complex, as some viewers formed unexpected relationships between images across the panels and made different paradigmatic choices of meaning to those of the maker, thereby constructing alternate readings of the installations. Images incorporated into the work with an expectation of shared readings were informed by viewers' personal and cultural experiences, their own memories and histories, and the boundaries of their wider social and historical knowledge, often creating divergence from the intended meaning of the narrative. When a substantial number of viewers drew the meaning of an image from a different paradigm to 
that of the maker, the dominant cultural paradigm that the image belonged to was revealed.

The influence of context on viewers' readings of the installation was evident in a small number of responses at each site in the study. Viewers drew on their knowledge of the social history of the area and the function of the site (e.g. a museum or a church) to inform their reading of the textile installations. When the textile panels were exhibited in Saltaire, local viewers' particularly drew on oral histories passed on through families to inform their responses to the narrative. At the Lloyds site in Birmingham the images of the crossed keys and single key (installation one) had greater impact on the reading of the narrative than at other sites due to the history of lock and key making in the area (which the maker was unaware of). This has wider implications for the exhibition of communicative textile artefacts, as each site brings its own history, associations and expectations which impact on the reading of the work, particularly with local viewers.

However, some common readings of the narrative and individual signifiers were evident across a substantial number of responses to the installations across the sites. These provided evidence that the textiles functioned as a mnemonic product with viewers at a group level (in addition to an individual level). Collective cultural memory informed a shared visual grammar that had greater influence than location on viewers' readings of the narrative in most cases.

\section{REFERENCES}

Andrew, S. 2008. Textile Semantics: Considering a Communication Based Reading of Textiles. In Textile: the Journal of Cloth and Culture, March (issue 6.1): 32-65.

Barnard, M. 1996. Fashion as Communication. London: Routledge.

Barthes, R. 1967. Elements of Semiology. London: Johnathan Cape. (Originally published in French by Editions du Seuil, Paris).

Bredif, J. 1989. Toile de Jouy. Paris: Adam Biro.

Davis, F. 1992. Fashion, Culture and Identity. Chicago: University of Chicago Press.

Eco, U. 1977. A Theory of Semiotics. London: Macmillan Press.

Erll, A., Nunning, A. \& Young, S.B. (eds.) 2008. Cultural Memory Studies: An International and InterDisciplinary Handbook. Berlin: Walter de Gruyter GmbH \& Co. KG.

Fiske, J. 2010. Introduction To Communication Studies (Studies in Culture and Communication). London: Routledge.

Hill, A. 2015. Dancing ninja dresses join battle against pink hordes. In The Guardian, (February 21st): 10.

Jefferies, J. 2008. Contemporary Textiles: the art fabric. In N. Monem (ed.) Contemporary Textiles, the fabric of fine art. London: Black Dog Publishing: 51.

Kaiser, S. 2002. The Social Psychology of Clothing: Symbolic Appearances in Context. New York: Fairchild Publications.

Kingswell, T. 1998. Red or Dead: the good, the bad and the ugly. London: Thames and Hudson.
Millar, L. 2007. Cloth \& Culture Now. Espom: University College for the Creative Arts.

Olick, J.K. 2010 From Collective Memory to the Sociology of Mnemonic Practices and Products' in Erll, A. and Nunning, A. (eds.) A Companion to Cultural Memory Studies. Berlin: Walter de Gruyter GmbH \& Co. KG.

Saussure, F. 1983. Course in General Linguistics. London: Duckworth. (Translated by R. Harris from the original version in 1916).

http://www.campaignlive.co.uk/article/galaxy-revive-silkstrapline-11-years/1112282 [accessed 20/04/2016] http://collections.vam.ac.uk/item/O110717/victory-v-dressfabric-calico-printers-association/ [accessed 20/04/2016] https://www.gov.uk/government/collections/bailey-review [accessed 01/07/17]

https://letclothesbeclothes.uk/category/dinosaurs-for-allcampaign/ [accessed 01/07/2017]

http://princess-awesome.com/collections/girls

[accessed 20/04/2016]

Further information on the research study is available in the following publications:

Andrew. S. 2014. Image and Interpretation: Encoding and Decoding a Narrative Textile Installation. In The Journal of Textile Design Research and Practice. Vol.2: 2 (November 2014): 153-186.

Andrew. S. 2013. The Medium Carries the Message? Perspectives on Making and Viewing Textiles. In The Journal of Visual Arts Practice. Vol. 12: 2 (August 2013): 195 - 221. 

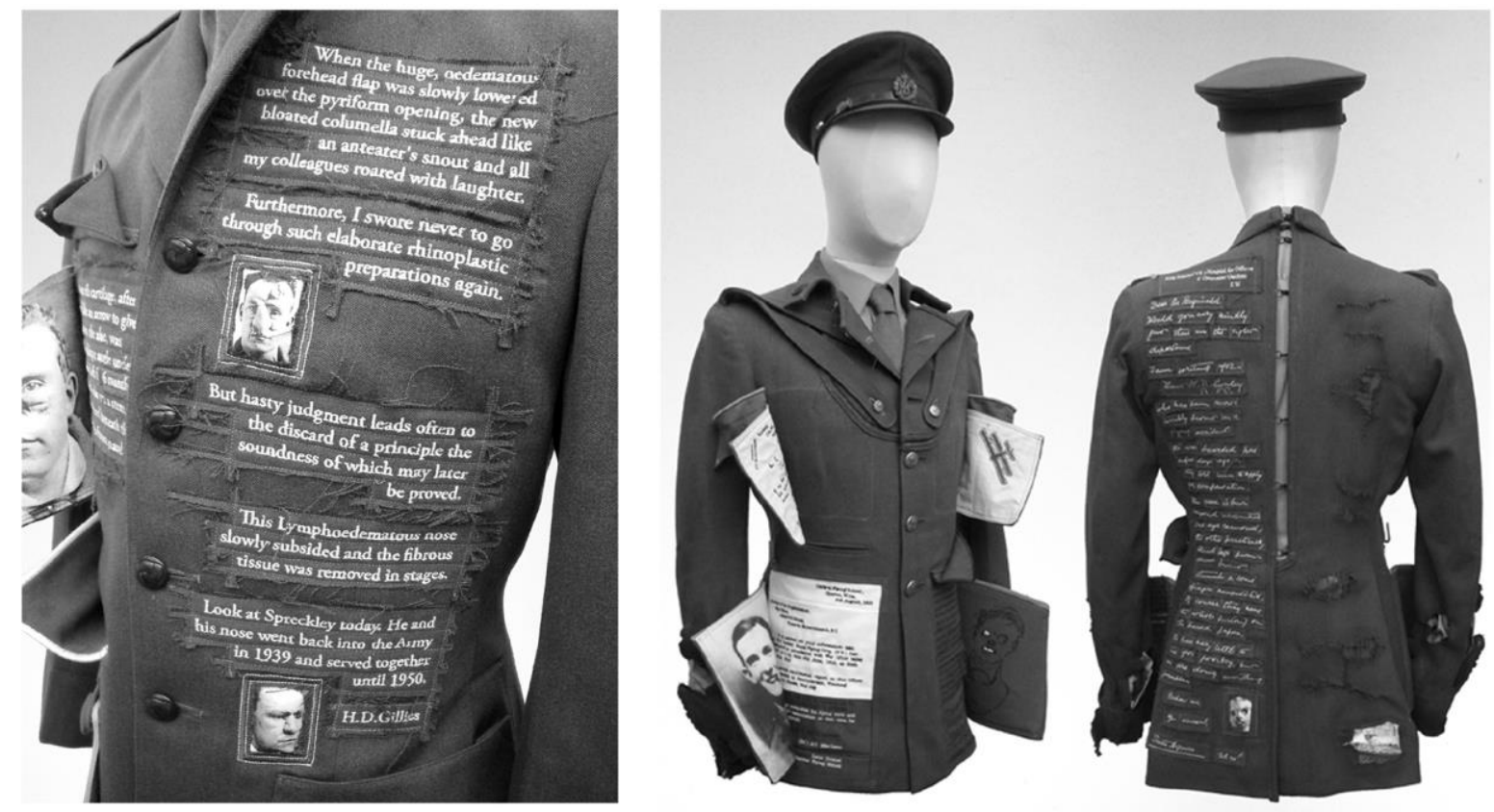

Figure 1: Left: 'Spreckley 2' (chest detail). Right: 'Lumley' (front and back view). Both by Paddy Hartley for the exhibition Project Façade (2007-2008). Images: courtesy of Paddy Hartley.
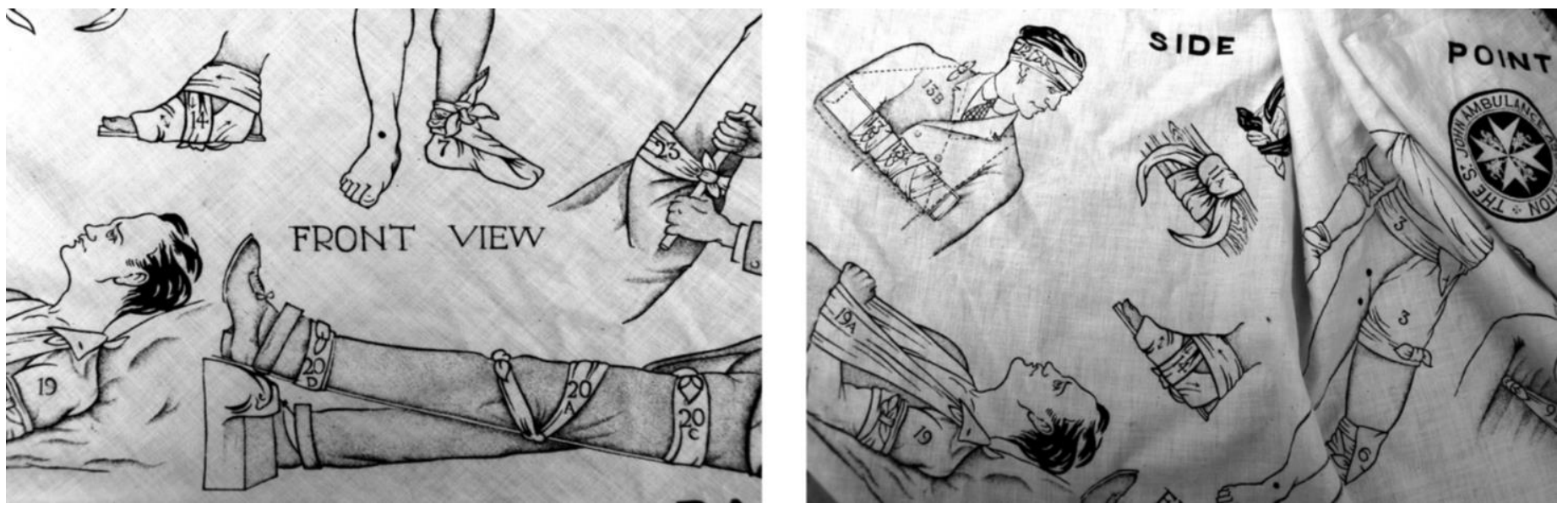

Figure 2. WW1 St John Ambulance sling (two details). Images courtesy of Janet Haigh.
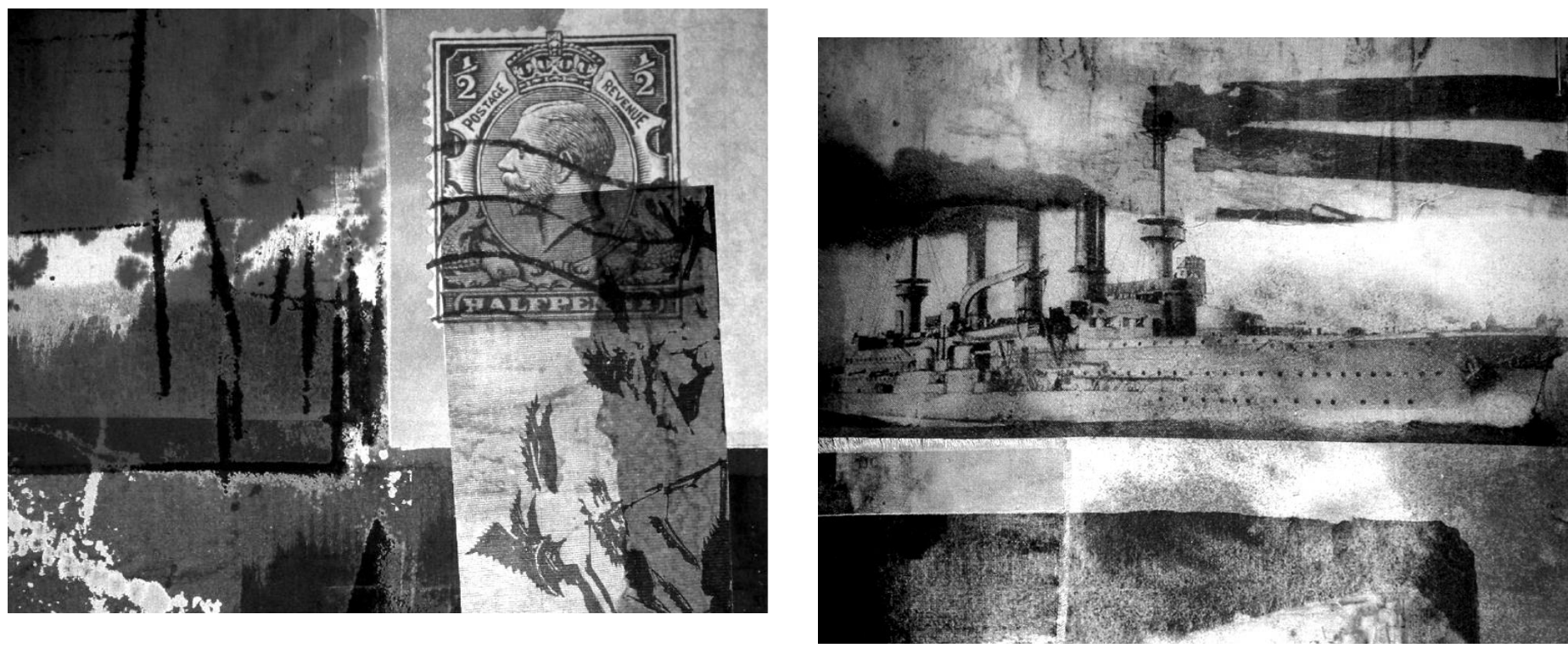

Figure 3. Stamp detail, panel one, installation one.

Figure 4. Ship detail, panel one, installation two. 


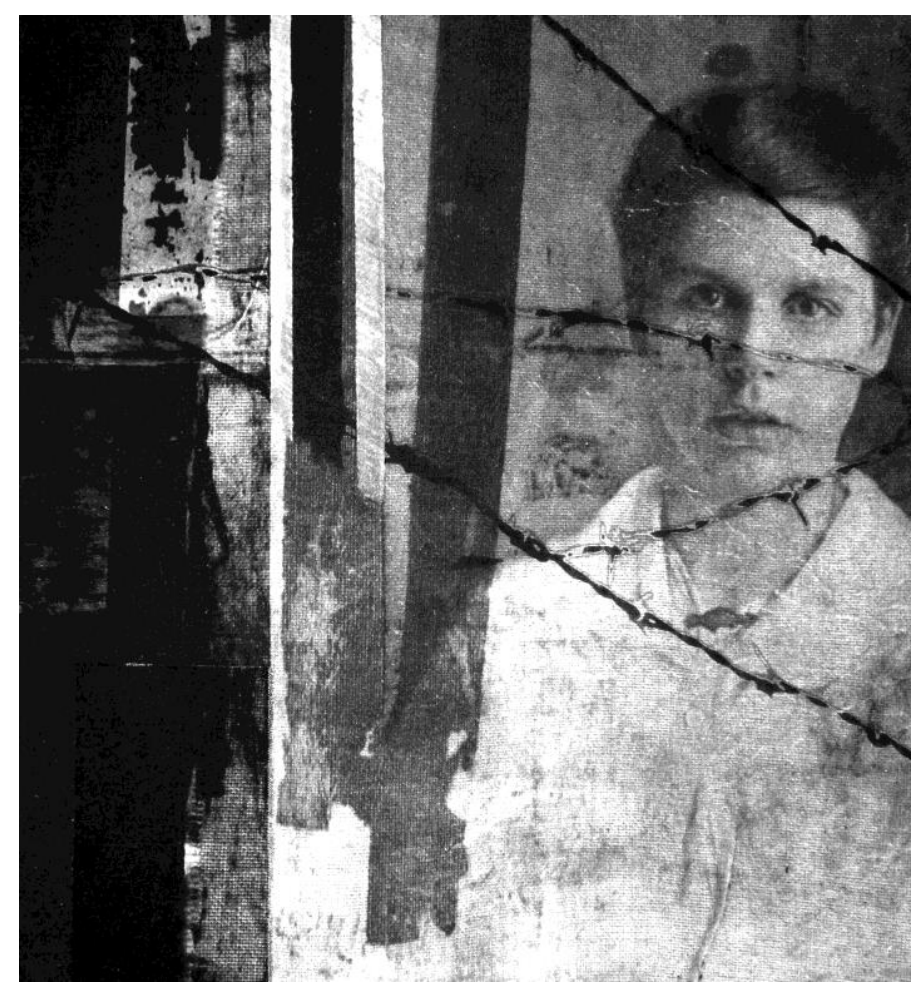

Figure 5: Woman and barbed wire detail, panel two, installation two. 